\title{
Pathology caused by adult Pseudochondracanthus diceraus (Copepoda: Chondracanthidae), a parasite of bullseye puffer fish Sphoeroides annulatus
}

Patología causada por adultos de Pseudochondracanthus diceraus (Copepoda: Chondracanthidae) parásito del botete diana Sphoeroides annulatus

\section{Emma Josefina Fajer-Ávila', Leslie Guzman-Beltran², Walter Camilo Zárate-Rodríguez², Oscar Basilio Del Río-Zaragoza ${ }^{1}$ and Pablo Almazan-Rueda ${ }^{1}$}

${ }^{1}$ Centro de Investigación en Alimentación y Desarrollo, A.C., Unidad Mazatlán en Acuicultura y Manejo Ambiental, Av. Sábalo Cerritos s/n, Estero del Yugo, C.P. 82010, Mazatlán, Sinaloa, México. efajer@ciad.mx

${ }^{2}$ Universidad de La Salle, Facultad de Medicina Veterinaria, Sede La Floresta, Carretera 7a No. 172-85, Bogotá DC, Colombia

\begin{abstract}
Resumen.- El copépodo condracántido Pseudochondracanthus diceraus es un parásito frecuente en las branquias del botete diana silvestre, Sphoeroides annulatus en Sinaloa, México. El presente estudio constituye la primera descripción de algunos parámetros sanguíneos y la histología branquial de S. annulatus infestados por hembras adultas de $P$. diceraus. Se aclimataron sesenta y dos peces silvestres en tanques experimentales por 15 días y a los 16 y 21 días se tomaron muestras para la realización de los análisis. Se observó un 100\% de prevalencia y una intensidad media de 7,16 (1-17) parásitos por pez. P. diceraus prefirió los sectores anteriores y posteriores de cada arco branquial. Los porcentajes de leucocitos fueron significativamente menores en peces con las más altas intensidades de infestación. La respuesta branquial del hospedero fue más pronunciada cerca del sitio de fijación del parásito y estuvo caracterizada por hiperplasia y fusión de las lamelas secundarias, hiperplasia condrocítica de las lamelas primarias, atrofia del epitelio lamelar e incremento del número de células mucosas. Los daños en el tejido branquial del botete diana son causados por las antenas grandes y robustas modificadas en forma de grapa que emplea el parásito para fijarse al pez. Esto indica que altas prevalencia e intensidades de infestación por $P$. diceraus representan un riesgo de salud potencial para el cultivo de esta especie de pez.
\end{abstract}

Palabras clave: Condracántidos, peces, hematología, histopatología, México

\begin{abstract}
The chondracanthid copepod Pseudochondracanthus diceraus is a parasite commonly found on the gills of wild bullseye puffer fish, Sphoeroides annulatus, in Sinaloa, Mexico. This paper provides the first description of some blood parameters and gill histology of wild bullseye puffer fish infected by an adult parasitic copepod $P$. diceraus. Sixty two wild fish were acclimatized for 15 days in experimental tanks, and then on days 16 and 21 , samples were taken. Results showed a $100 \%$ prevalence and a mean intensity of $7.16(1-17)$ copepods per fish. $P$. diceraus preferred the anterior and posterior sector of each gill arch. The percentage of leukocytes was significantly lower in fish with the highest intensity of infection. The gill response of the host was most evident near the parasite's attachment site. It was characterised by hyperplasia and fusion of secondary lamellae, chondrocyte hyperplasia of primary lamellae, atrophy of the lamellar epithelium and an increase in the number of mucous cells. The damaged gill tissue of the bullseye puffer fish was caused by the large and strong antennae of $P$. diceraus that is modified as a claw to attach to the host gills. Thus, a high prevalence and intensity of this copepod could become a potential health risk to the bullseye puffer fish culture.
\end{abstract}

Key words: Chondracanthid, fish, haematology, histopathology, Mexico

\section{INTRODUCTION}

The bullseye puffer fish Sphoeroides annulatus (Jenyns, 1842 ) is a tetraodontid species inhabiting the Gulf of California, extending along the Eastern Pacific coast from San Diego (USA) to Peru (Thomson et al. 2000). Biotechnological advances have made it possible to cultivate the bullseye puffer in Sinaloa, Mexico (AlvarezLajonchere et al. 2007). However, under culture conditions, juvenile fish have recurrent infections by ectoparasitic copepods that have resulted in high mortalities (FajerÁvila et al. 2008). 
Gill pathology caused by ectoparasitic copepods has great economic importance for some species (Lin et al. 1994, Wu et al. 1997, Bennett \& Bennett 2001, Smith et al. 2007, Tang et al. 2007). Three copepods belonging to the families Lernaeopodidae, Bomolochidae and Chondracanthidae were found on gills and in the branchial cavity of wild bullseye puffer fish from Mazatlán, Sinaloa, Mexico (Fajer-Ávila et al. 2004). The Chondracanthidae was represented by Pseudochondracanthus diceraus Wilson, 1908 and it was the most abundant copepod (Morales-Serna 2010). However, there is a lack of information on the pathology associated with this parasitic copepod.

High abundances of parasites on fish usually cause alterations in several blood parameters because some of them feed on host blood (Chavez et al. 2006, Sitjà-Bobadilla \& Alvarez-Pellitero 2009). Hematological analysis could therefore be used as a direct or inferential indicator of the tolerance to a stressor agent or/and health of the fish (Schreck \& Moyle 1990, Del Rio-Zaragoza et al. 2008). In order to address such an approach, it is necessary to thoroughly characterize the blood cells of the organisms and use this knowledge to quantify normal blood parameters (Shigdar et al. 2007). This paper provides the first description of the pathology caused by adult females of the copepod Pseudochondracanthus diceraus on the gills of Sphoeroides annulatus using histopathological and haematological analyses.

\section{Materials AND Methods}

\section{EXPERIMENTAL DESIGN}

Sixty two bullseye puffer fish, Sphoeroides annulatus, with an average weight of $223.2 \pm 35.8 \mathrm{~g}$ and an average total length of $21 \pm 1.2 \mathrm{~cm}$, were caught from Santa María de La Reforma Bay $\left(25^{\circ} 10^{\prime} \mathrm{N}, 108^{\circ} 20^{\prime} \mathrm{W}\right.$ and $24^{\circ} 50^{\prime} \mathrm{N}$, $107^{\circ} 55^{\prime} \mathrm{W}$ ) Sinaloa, Mexico and were transported alive in $450 \mathrm{~L}$ circular tanks to CIAD's laboratory facilities. Upon arrival, six fish were randomly selected, anaesthetised with 2 phenoxyethanol $0.75 \mathrm{~mL} \mathrm{~L}^{-1}$ (Sigma, St. Louis) for $3 \mathrm{~min}$ and gills were excised to be analysed for adult copepods. All fish were only infected by the chondracanthid Pseudochondracanthus diceraus with an initial mean intensity of 4.16 parasites per fish. The rest of the fish were randomly distributed into four $400 \mathrm{~L}$ circular tanks (14 fish per tank) with mesh-filtered $(20 \mu \mathrm{m})$ flow through seawater (SW) and aeration. Fish were fed a mixture of frozen tilapia fillet, squid and shrimp at $5 \%$ of their body weight twice per day. Fish were acclimatized during 15 days. After this period, on days 16 and 21, three fish per tank were sampled for parasites, blood parameters and gill histology (24 fish in total). During the trial fish did not show signs of viral/bacterial disease. The rest of the fish (26) were used for other studies.

\section{Haematological parameters}

Fish were anaesthetised and in less than three min, blood samples were collected from the caudal vein using 3-ml non-anticoagulant syringes (Terumo Mexico, DF). Immediately after sampling, one blood drop was used for blood smears. Then, the blood sample was placed into tubes coated with anticoagulant ( $\mathrm{K}_{2}$ EDTA BD Microtainer) for haematocrit and haemoglobin. Haematocrit (HCT) was calculated after using a CORNING heparinised tube, filled to $2 / 3 \mathrm{rds}$, and was placed for $10 \mathrm{~min}$ in a SOL-BAS P600 microhaematocrit centrifuge. The packed cell percentage versus the total volume was measured using a microhaematocrit reader and reported as a percentage. Haemoglobin (HGB) concentration in the blood was determined by the cyanomethaemoglobin method with a hemogloWiener ${ }^{\circledR}$ kit and the aid of an absorbance spectrophotometer (Agilent $\left.{ }^{\circledR} 8453\right) \lambda=540 \mathrm{~nm}$. Mean corpuscular haemoglobin concentration (MCHC) was calculated using the following standard formula: $\mathrm{MCHC}$ $\left(\mathrm{g} \mathrm{dL}^{-1}\right)=\mathrm{Hb}\left(\mathrm{g} 100 \mathrm{ml}^{-1}\right) \times 100 / \mathrm{Ht}(\%)$. For each fish, triplicates of all blood parameters were completed. Leukocyte cellular differentiation was observed in blood smears treated with Wright-Giemsa staining in an optical microscope (LEICA DMLB-10, Guadalajara). The images were processed using Image-Pro Plus 3 software (Media Cybernetics, Bethesda). Thirty digital images with an average of $214.58 \pm 55.33$ leukocytes at $600 \mathrm{X}$ were captured from each blood smear and the percentages of each cell type were calculated. An OLYMPUS BX-51 optical microscope was used to measure the erythrocyte, thrombocyte and leucocyte diameters $(n=30$ cells $)$.

\section{Parasitological and histopathological EXAMINATION}

After blood collection, the gill arches were dissected, placed in Petri dishes with drops of filtered seawater (34 psu) and the parasites from each gill arch were counted using a Leica MZ 9.5 stereomicroscope (Leica Microsystems Wetzlar, Germany). The bullseye puffer fish is an exceptional teleost fish with only three gill arches in each side. The gill arches were numbered I to III from external to internal arch, on each side of the fish. Also, each arch was arbitrarily divided into three sectors 
approximately equal in surface area: anterior (A), central (B) and posterior (C). To analyse the gills for parasites, each gill arch was individually placed in a Petri dish with drops of seawater and observed under a stereomicroscope, and then the number of parasites per sector (anterior to posterior) was counted. Each gill arch was fixed in $10 \%$ neutral buffered formalin. Twenty four $\mathrm{h}$ later the gills were removed from formalin and preserved in ethanol $(70 \%)$.

Prevalence (\%) and mean intensity of Pseudochondracanthus diceraus in the fish were defined according to Bush et al. (1997). The condition factor $(K)$, was calculated according to Ricker (1975).

Small pieces of gill arch infected and uninfected with copepods were embedded in paraffin wax for histopathological analysis. Tissue sections of 3-5 $\mu \mathrm{m}$ thicknesses were obtained using a conventional microtome. Each sample was dehydrated and stained with haematoxylin-eosin-phloxin. Samples were observed and photomicrography was carried out using an OLYMPUS BX51 microscope. Evaluation of severity and extent of injury on gill arch tissue was recorded according to Bernet et al. (1999). A brief description is as follows: Low level: cell and tissue structure slightly injured and visible. Moderate level: reduced activity of the injured cells and tissue, and High level: high cell activity and loss of tissue function and structure. The gill arch is severely damaged, making identification very difficult.

\section{Statistical analysis}

Results were expressed as means \pm standard deviation (SD) or standard error (SE). Normality tests were performed for all data. For the distribution of $P$. diceraus on the gill arch of the fish, data was analysed by the Kruskal-Wallis test. To determine significant differences amongst groups, a multiple comparison analysis 'a posteriori' Tukey test was carried out and for the blood parameters a Student's $t$-Test $(P<0.05)$ was applied. All percentage data were arcsine transformed before statistical comparisons. Non-normal data were analyzed by the Mann-Whitney Rank Sum Test (U). Spearman's correlation coefficient between blood parameters and level of infestation was calculated. All analysis was realized using SigmaPlot 9 software (SYSTAT Software, Inc., San Jose).

\section{ReSUlTS}

\section{NuMBERS AND DISTRIBUTION OF PARASITES}

In total 24 fish were analysed and 208 Pseudochondracanthus diceraus adults were found (Fig. 1 ), with a prevalence of $100 \%$ and a mean intensity of 7.16 parasites per fish, with a range from 1 to 17 . P. diceraus had an average length of $3 \mathrm{~mm}$ and average width of 1 $\mathrm{mm}$. Significantly more $P$. diceraus adults were found in the anterior and posterior sectors of the gill arch (Fig. 2) compared to the central sector $(P<0.05)$, and no preference for any particular gill arch $(P>0.05)$ was observed. No differences for sampling days 16 and 21 were found in respect to the numbers of parasites and condition factor. So, independent of sampling time, an arbitrary categorization of two levels of infection was carried out according to the total number of parasites foun on the three gill arches: 1 (1-6 parasites) and 2 (7-17 parasites). Blood parameters were also analyzed based on this categorization.

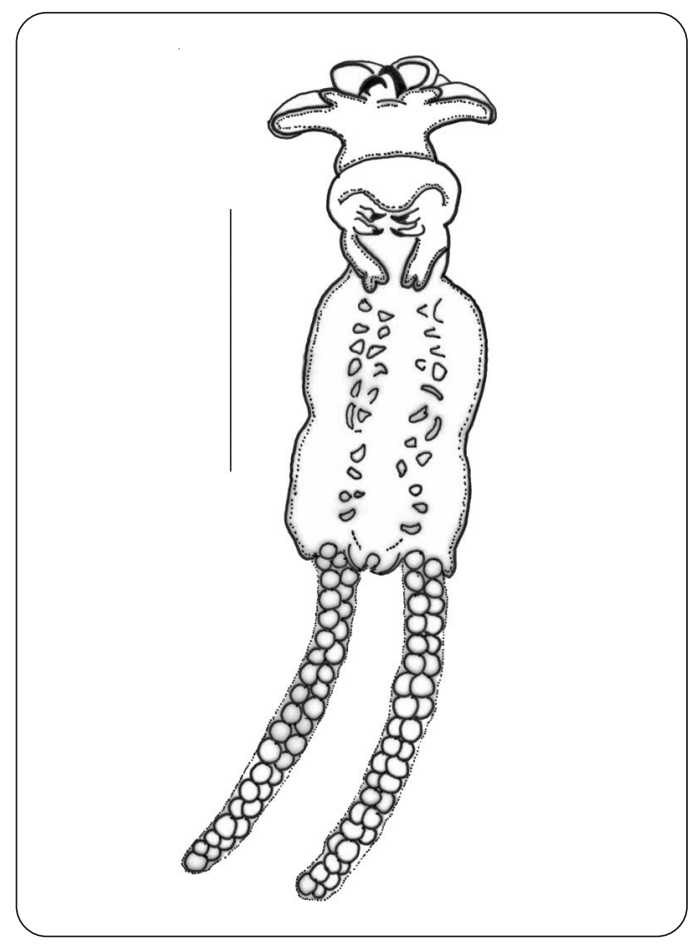

Figure 1. Ventral view of a Pseudochondracanthus diceraus female adult with eggs. Scale bar $=2 \mathrm{~mm} /$ Vista ventral de la hembra adulta ovígera de Pseudochondracanthus diceraus. Barra de escala $=2 \mathrm{~mm}$ 


\section{Haematology}

The blood cells (Fig. 3) were identified and characterized by light microscopy as follows: Erythrocytes had an average diameter of $7.61 \pm 0.66 \mu \mathrm{m}$. These blood cells have an elliptical shape, well defined nucleus, thin chromatin, violet colour and transparent-grey cytoplasm. Immature erythrocytes were rounded in shape and fewer in number than mature ones. Thrombocytes were oval in shape with an elongate purple nucleus and violet cytoplasm when observed. The average length of thrombocytes was $7.28 \pm 0.59 \mu \mathrm{m}$. Lymphocytes were the most abundant of the different leukocytes. Lymphocytes have a rounded shape with an average diameter of $5.06 \pm$ $0.52 \mu \mathrm{m}$. The nucleus was violet with a thin chromatin and most of the cytoplasm is occupied by the nucleus. The colour of the cytoplasm is dark blue. Some of these cells had pseudopods. Granulocytes were the second most frequently found type of leukocyte. Granulocytes are larger than lymphocytes but smaller than monocytes, with an average diameter of $8.38 \pm 0.80 \mu \mathrm{m}$. Granulocytes are rounded in shape and have a oval or reniform nucleus of violet colour located away from the center of the cell, and a transparent grey cytoplasm. Eosinophilic granulocytes were found as a small proportion of the leukocytes. The size of these cells varied according to the quantity and size of the eosinophilic granules inside of the cell. In the present study, no basophilic granulocytes were observed. Monocytes were the least frequent leukocyte, however, they were the largest cell type with an average diameter of $9.82 \pm 0.74 \mu \mathrm{m}$. Monocytes are usually round in shape, but were sometimes irregular in outline. Monocytes have a large, irregular, violet nucleus with thin chromatin; the blue cytoplasm sometimes had vacuoles.

Blood parameters in the bullseye puffer fish under two different intensities of infection by Pseudochondracanthus diceraus are summarised in Table 1. Infection intensities from 7 to 17 parasites per fish resulted in a significant reduction in the percentage of leukocytes and tended to reduce the haemoglobin (HGB) levels and the average concentration of haemoglobin (MCHC). However, there was no significant difference between the two intensities of infection for HT $(P=0.708), \operatorname{HGB}(P=0.515)$ and MCHC $(P=0.528)$ (Table 1). Also there were no significant differences in the percentages of erythrocytes, lymphocytes, monocytes, granulocytes and thrombocytes (Table 1). There was no correlation between the blood parameters of the bullseye puffer fish and the intensity of infection of adult $P$. diceraus.

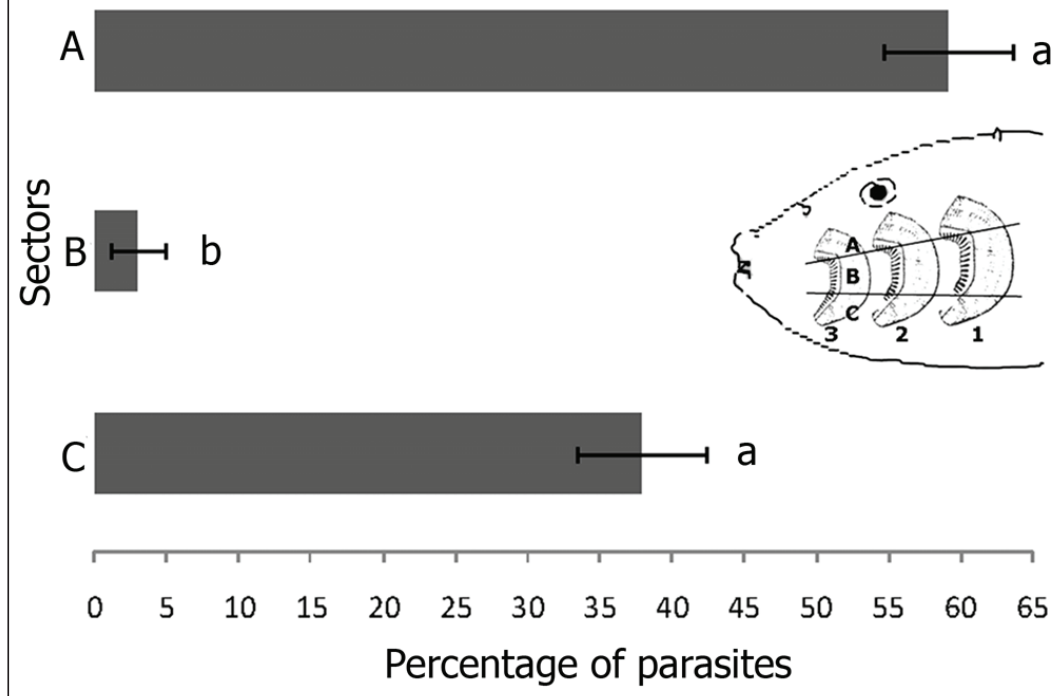

Figure 2. Distribution of Pseudochondracanthus diceraus on the gill arch of the bullseye puffer fish Sphoeroides annulatus in three sectors: A) anterior, B) central and C) posterior. Data are mean \pm standard error (SE). Sample size (n = 24). Different letters indicate significant difference $(P<0.05)$ / Distribución de Pseudochondracanthus diceraus sobre los arcos branquiales del botete diana, Sphoeroides annulatus en tres sectores: A) anterior, B) central y C) posterior. Los datos son media \pm error estándar (SE). Tamaño de muestra $(n=24)$. Letras diferentes indican diferencia significativa $(P<0,05)$ 


\section{Histopathology}

Lamellar cell disruption was characterised according to three levels of severity and extent of the pathology to where the parasite was attached. The lowest degree of severity was a mild focal hyperplasia of epithelium and a fusion of the secondary lamellae with a slight increase in the number of mucous cells associated with the presence of the copepod (Fig. 4a).
There was chondrocyte hyperplasia of the primary lamellae adjacent to site of Pseudochondracanthus diceraus attachment along with high numbers of mucous cells and mild to moderate hyperplasia of the lamellar epithelium (Fig. 4b). At this stage the severity and the extent of the pathology was considered moderate. The highest degree of severity was characterized by atrophy and hyperplasia of the epithelium and connective tissues
Figure 3. Micrograph of blood smears showing: Erythrocytes (E), Lymphocytes (L), Granulocytes (G), Monocytes (M) and Thrombocytes $(T)$ of the bullseye puffer fish Sphoeroides annulatus (bar $=10 \mu \mathrm{m}$ ) / Microfotografía de un frotis sanguíneo de botete diana, Sphoeroides annulatus (barra $=10 \mu \mathrm{m})$ mostrando: Eritrocitos (E), Linfocitos (L), Granulocitos (G), Monocitos (M) y Trombocitos (T)

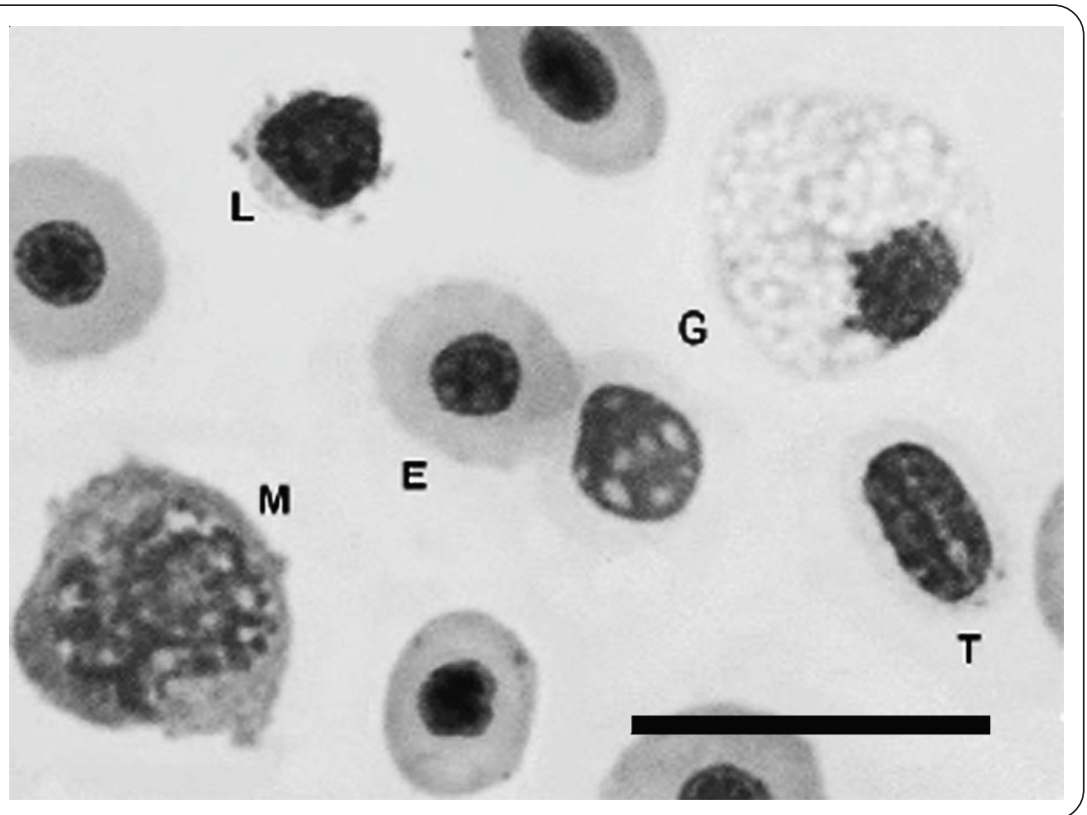

Table 1. Blood parameters of the bullseye puffer fish, Sphoeroides annulatus, at two different intensities of infection by Pseudochondracanthus diceraus / Parámetros sanguíneos del botete diana, Sphoeroides annulatus, asociados a dos diferentes intensidades de infestación con adultos de Pseudochondracanthus diceraus

\begin{tabular}{|c|c|c|c|c|}
\hline \multirow[t]{2}{*}{ Parameters } & \multicolumn{2}{|c|}{ Intensity of infection } & \multicolumn{2}{|c|}{$\begin{array}{c}\text { Student's } t \text {-test or Mann- } \\
\text { Whitney Test }\end{array}$} \\
\hline & $1-6$ & $7-17$ & $t$ or $\mathrm{U}$ & $P$ \\
\hline Haematocrit (\%) & $\begin{array}{c}32 \pm 4.27 \\
(\mathrm{n}=11)\end{array}$ & $\begin{array}{c}32 \pm 6.32 \\
(n=6)\end{array}$ & 0.0922 & 0.928 \\
\hline Haemoglobin (g/dL) & $\begin{array}{c}6.1 \pm 2.60 \\
(\mathrm{n}=11)\end{array}$ & $\begin{array}{c}4.9 \pm 0.82 \\
(\mathrm{n}=6)\end{array}$ & 51.000 & 0.802 \\
\hline $\mathrm{MCHC}(\mathrm{g} / \mathrm{dL})$ & $\begin{array}{c}18.9 \pm 7.79 \\
(\mathrm{n}=11)\end{array}$ & $\begin{array}{l}15.75 \pm 2.40 \\
\quad(n=6)\end{array}$ & 45.000 & 0.393 \\
\hline Erythrocytes (\%) & $\begin{array}{c}93.08 \pm 1.32 \\
\quad(n=13)\end{array}$ & $\begin{array}{c}93.88 \pm 0.77 \\
(n=11)\end{array}$ & -1.755 & 0.093 \\
\hline Leukocytes (\%) & $\begin{array}{c}4.52 \pm 1.04 \\
(\mathrm{n}=13)\end{array}$ & $\begin{array}{c}3.59 \pm 0.75 \\
(\mathrm{n}=11)\end{array}$ & 97.000 & 0.020 \\
\hline Lymphocytes (\%) & $\begin{array}{c}84.96 \pm 7.35 \\
(n=13)\end{array}$ & $\begin{array}{l}86.22 \pm 6.06 \\
\quad(n=11)\end{array}$ & -0.465 & 0.647 \\
\hline Granulocytes (\%) & $\begin{array}{c}12.34 \pm 6.38 \\
(n=13)\end{array}$ & $\begin{array}{l}12.30 \pm 5.26 \\
(n=11)\end{array}$ & -0.100 & 0.921 \\
\hline Monocytes (\%) & $\begin{array}{l}2.62 \pm 2.40 \\
(\mathrm{n}=13)\end{array}$ & $\begin{array}{c}1.45 \pm 1.61 \\
(\mathrm{n}=11)\end{array}$ & 1.581 & 0.128 \\
\hline Thrombocytes (\%) & $\begin{array}{c}2.37 \pm 0.87 \\
\quad(n=13)\end{array}$ & $\begin{array}{l}2.51 \pm 0.71 \\
(\mathrm{n}=11)\end{array}$ & -0.477 & 0.638 \\
\hline
\end{tabular}

All the data are mean \pm SD. $n=$ number of fish analysed for each parameter 
(Fig. 4c). Infiltration of leukocytes was observed. Also, obstruction of blood flow occurred due to the lamellar vessels constriction.

\section{Discussion}

Different authors have found that gill ectoparasites (monogeneans and copepods) were restricted to a particular area inside the gill cavity of the host (Geets et al. 1997, Lo \& Morand 2001, Timi 2003).
Pseudochondracanthus diceraus preferred the anterior and posterior sectors of the bullseye puffer gills indicating specific microhabitats on the gill arch. This preference could be related to low water flow and low water volumes compared to the central sector of the gill (Hughes 1970, Perna \& Fernández 1996), which seems to reduce the probabilities of $P$. diceraus being detached. Another hypothesis to be considered is the aggregation of parasites in a specific microhabitat to enhance the chance to mate (Rohde et al. 1995).
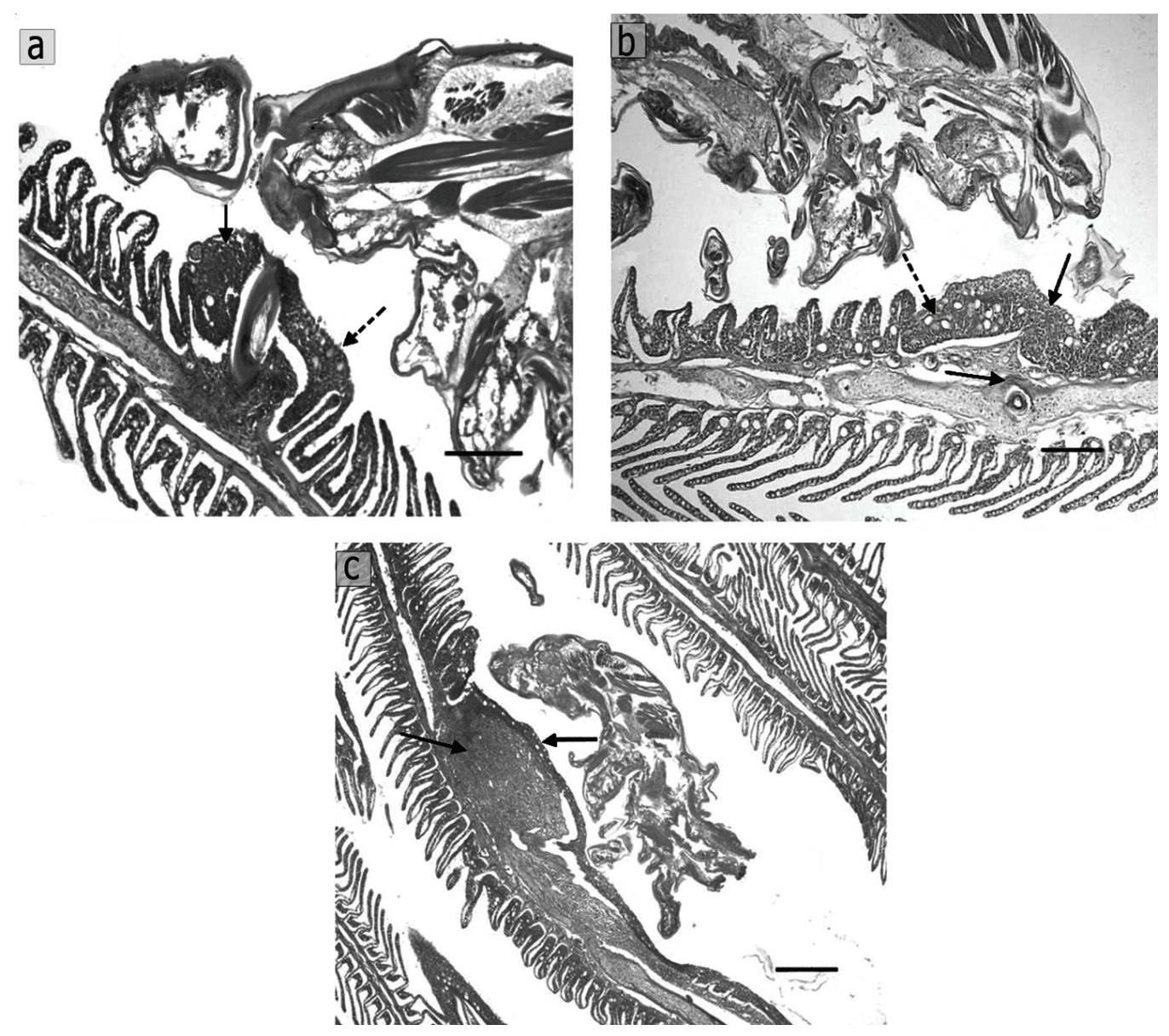

Figure 4. Histopathology of gills associated with the presence of the Pseudochondracanthus diceraus according to three levels of severity on the bullseye puffer fish Sphoeroides annulatus. a) Low level of severity. Secondary lamellae show mild hyperplasia and a slight increase in the number of mucous cells $(b a r=100 \mu \mathrm{m})$. b) Moderate level of severity. Gill filament shows chondrocyte hyperplasia of the primary lamella adjacent to site of Pseudochondracanthus diceraus attachment. High numbers of mucous cells and mild to moderate hyperplasia of the lamellar epithelium $(b a r=100 \mu \mathrm{m})$. c) High level of severity. Lamellae show atrophy and hyperplasia of the epithelium and connective tissues $(\mathrm{bar}=200 \mu \mathrm{m})$. Solid arrow and segment arrows show epithelial hyperplasia and mucous cells, respectively / Histopatología branquial del botete diana, Sphoeroides annulatus, asociada a tres niveles de severidad por Pseudochondracanthus diceraus. a) Nivel de severidad bajo. Hiperplasia leve de las lamellas secundarias y ligero incremento del número de células mucosas (barra $=100 \mu \mathrm{m}$ ). b) Nivel de severidad moderado. El filamento branquial muestra hiperplasia condrocítica de la lamella primaria adyacente al sitio de adhesión de Pseudochondracanthus diceraus. Abundantes células mucosas e hiperplasia moderada del epitelio de las laminillas branquiales (barra $=100 \mu \mathrm{m}$ ). c) Nivel de severidad alto. Atrofia e hiperplasia del tejido epitelial y conectivo (barra $=200 \mu \mathrm{m})$. Las flechas sólidas y segmentadas muestran hiperplasia epitelial y células del moco, respectivamente 
The blood cells of the bullseye puffer fish were consistent with the typical characteristics of marine fish (Palíková et al. 1999, Rough et al. 2005, Pavlidis et al. 2007), and freshwater fish (Conroy 1972, Ellis et al. 1989, Hrubec et al. 2000) except that the erythrocytes are smaller than those of the other marine fish species reported by Rough et al. (2005) and Pavlidis et al. (2007). The difference in the erythrocyte size may be linked to a sedentary life style of the bullseye puffer fish. This is in agreement with Larsson et al. (1976) who hypothesised that fish with more active life styles had larger erythrocytes than those with a sedentary life style. However, differences in sizes of blood cells between fish species reinforce the necessity to thoroughly characterise each species separately (Shigdar et al. 2007). The classification of certain types of leukocytes can also be hampered by inconsistencies in nomenclature and the form of some cells (Cannon et al. 1980, Barber et al. 1981). Tierney et al. (2004) mentioned that small lymphocytes and thrombocytes can be nearly identical, large lymphocytes can appear in a variety of hues, textures and shapes, so that they can be confused with monocytes and granulocytes, which sometimes are referred as heterophils or neutrophils.

In the present study the values of HCT, HGB and HCMC, regardless of the intensity of $P$. diceraus (for up to a maximum of 17) indicate that this parasite did not cause blood loss or anaemia. In contrast, Bennett \& Bennett (2001) found that fish had severe focal haemorrhage due to the penetration of the maxillipeds of the parasite copepod Dissonus manteri into the primary lamella of the leopard coral grouper Plectropomus leopardus, and anaemia was shown to be caused by Lernaeocera branchialis in haddock Melanogrammus aeglefinus (Lester \& Roubal 1995), cod Gadus morhua (Khan et al. 1990) and hake Merluccius merluccius (Guillaume et al. 1985).

On the other hand, a significantly smaller percentage of leukocytes in the blood were found in bullseye puffer fish with an infestation of 7-17 parasites per fish. This is important because fish leukocytes are involved in regulation of immunological function (Santhakumar et al. 1999) and the reduced number of leukocytes may have been due to stress caused by the parasite. This suggests a connection between parasitic infestations and impaired immunological responses. A reduced number of leukocytes also have been found in the snakehead murrel Channa striatus naturally infected with the isopod Alitropus typus (Achuthan-Nair \& Balakrishnan-Nair
1983); moreover in Schizodon intermedius infected by the copepod Lernaea cyprinacea (Silva-Souza et al. 2000) and in black scorpionfish Scorpaena porcus naturally infected by the leech Trachelobdella lubrica (Celik \& Aydin 2006).

The evaluation of blood parameters can be the fastest way to detect stress symptoms. Infectious diseases and stress can elevate the number of neutrophils and monocytes in blood (Ellsaesser \& Miller 1985) and decrease the number of lymphocytes as a protective response against the stress (Del Rio-Zaragoza et al. 2010). The numbers of lymphocytes, monocytes and neutrophils are considered as secondary responses in different kinds of stresses (Martins et al. 2004). However, contrary to expectation, the percentage of granulocytes did not increase at the highest level of infection due probably to the number of parasites, despite the increase of leukocytes observed in the gill tissue. These results are similar to the responses in some infected fish by some superficially attached ergasilid copepods (Paperna \& Zwerner 1982, Roubal 1989a). Chronic infection by copepod gill parasites can result in low to moderate infiltration of leukocytes to chronic inflammation seen in the surf bream Acanthopagrus australis on gill filaments infected with the lenaepodid copepod Alella macrotrachelus (Roubal 1989b).

The condition factor has been used as an indicator of the health status of a fish, and is useful to compare fish from different stocks (Weatherley \& Gill 1987). The results of this study indicate that the numbers of parasites per fish were not high enough to cause a reduction in the condition factor despite the gill injuries observed.

The localised hyperplasia at the site of attachment of Pseudochondracanthus diceraus was spread to the entire gill filament, losing its lamellar structure, and extended onto adjacent uninfected filaments. This can partly be attributable to the action of the strong and well-developed mouthparts of this copepod during their feeding (Ho et al. 2000) as well as for other sessile copepods, and the movement of the thorax and appendages to ensure water movement over the egg sacs so to avoid the settling of mucus debris, as similarly reported by Andrew et al. (2010) for Chondracanthus goldsmidi. In addition to the lamellar vessels constriction, deprivation of blood supply can occur by $P$. diceraus. As a result, copious mucous is produced, forming a thick coating in the gill area that diminishes the respiratory efficiency. Andrews et al. (2010) reported extensive epithelial hyperplasia and necrosis of gill tissue and 'papilloma-like' growths surrounding the 
entire parasite resulting in deformation of the filament in striped trumpeter, Latris lineata infested by Chondracanthus goldsmidi. Similar epithelial hyperplasia was found in the gills of bullseye puffer associated with the presence of $P$. diceraus, in contrast with the nodules formed by connective tissue described by Roubal (1999) and Bennett \& Bennett (2001) for the puffer Tetractenos hamiltoni (Richardson) and Plectropomus leopardus (Lacépède) parasitised by the copepods Naobranchia variabilis and Dissonus manteri, respectively. This tissue response improves the possibility of the parasites becoming attached to the host. Chronic infestations by parasites can lead to a high number of inflammatory cells through the entire gill filament; including neutrophils, thrombocytes, lymphocytes, and macrophages (Ferguson 2006). In contrast, we only found a mild number of leukocytes corresponding to the pathology described associated to $P$. diceraus on the bullseye puffer.

The genus Pseudochondracanthus was reported for Paralichthyidae and Tetraodontidae fish families (Boxshall $\&$ Halsey 2004). However, P. diceraus has shown a high specificity to their host and site of infection favouring tetraodontids fish, in particular the Sphoeroides genus. Prevalence of up to $67 \%$ of $P$. diceraus on wild $S$. annulatus from Santa María, La Reforma, Sinaloa, Mexico was reported by Morales-Serna (2010). Female of $P$. diceraus have large bodies with a pair of strong claw antennae capable to attach to the gill filaments, whose locking mechanism and feeding activities damage the gill tissue of the bullseye puffer fish. Thus, a high prevalence and intensity of this copepod could become a potential health risk to the bullseye puffer fish culture.

\section{ACKNOWLEDGEMENTS}

Thanks are given to R. M. Medina-Guerrero and S. AbadRosales for their technical assistance and to F. N. MoralesSerna for the specific identification of $P$. diceraus. Also, we thank the fishermen from Bahia de la Reforma, Navolato, Sinaloa, Mexico for their help in collecting the fish.

\section{LITERATURE CITED}

Achuthan-Nair G \& N Balakrishnan-Nair. 1983. Effect of infestation with the isopod, Alitropus typus M. Edwards (Crustacea: Flabellifera: Aegidae) on the haematological parameters of the host fish, Channa striatus (Bloch). Aquaculture 30: 11-19.

Alvarez-Lajonchere L, MA Reina-Cañez, MA CamachoHernández \& S Kraul. 2007. Design of a pilot-scale tropical marine finfish hatchery for a research centre at Mazatlan, Mexico. Aquacultural Engineering 36: 81-96.
Andrews M, S Battaglene, J Cobcroft, M Adams, E Noga \& B Nowak. 2010. Host response to the Chondracanthus goldsmidi, a gill parasite of the striped trumpeter, Latris lineata (Forster), in Tasmania. Journal of Fish Diseases 33: 211-220.

Barber DL, JE Mills-Westermann \& MG White. 1981. The blood cells of the Antarctic icefish Chaenocephalus aceratus Lönnberg: light and electron microscopic observations. Journal of Fish Biology 19: 11-28.

Bennett SM \& MB Bennett. 2001. Gill pathology caused by infestation of adult and preadult Dissonus manteri Kabata (Copepoda: Dissonidae) on coral trout, Plectropomus leopardus (Lacépède) (Serranidae). Journal of Fish Diseases 24: 523-533.

Bernet D, H Schmidt, W Meier, P Burkhardt-Holm \& T Wahli. 1999. Histopathology in fish: proposal for a protocol to assess aquatic pollution. Journal of Fish Diseases 22: 25-34.

Boxshall GA \& SH Halsey. 2004. An introduction to copepod diversity. Part 1, 421 pp. The Ray Society, London.

Bush A, KD Lafferty, JM Lotz \& AW Shostak. 1997. Parasitology meets ecology on its own terms: Margolis et al. revisited. Journal of Parasitology 83: 575-583.

Cannon MS, HH Mollenhauer, TE Eurell, DH Lewis, AM Cannon \& C Tompkins. 1980. An ultrastructural study of the leukocytes of the Channel Catfish, Ictalurus punctatus. Journal of Morphology 164: 1-23.

Celik ES \& S Aydin. 2006. Effect of Trachelobdella lubrica (Hirudinea: Piscicolidae) on biochemical and haematological characteristics of black scorpion fish (Scorpaena porcus, Linnaeus 1758). Fish Physiology and Biochemistry 32: $255-260$

Chavez IS, R Luvizzotto-Santos, LAN Sampaio, A Bianchini \& PE Martínez. 2006. Immune adaptive response induced by Bicotylophora trachinoti (Monogenea: Diclidophoridae) infestation in pompano Trachinotus marginatus (Perciformes: Carangidae). Fish and Shellfish Immunology 21: 242-250.

Conroy DA. 1972. Studies on the haematology of the Atlantic salmon Salmo salar. Symposia of the Zoological Society of London 30: 101-127.

Del Rio-Zaragoza OB, M Hernández-Rodríguez \& LF Bückle-Ramirez. 2008. Thermal stress effect on tilapia Oreochromis mossambicus (Pisces: Cichlidae) blood parameters. Marine and Freshwater Behaviour and Physiology 41: 135-145.

Del Rio-Zaragoza OB, EJ Fajer-Ávila \& P Almazán-Rueda. 2010. Haematological and gill responses to an experimental infection of dactylogyrid monogeneans on the spotted rose snapper Lutjanus guttatus (Steindachner, 1869). Aquaculture Research 41: 1592-1601. 
Ellis AE, RJ Roberts \& P Tyler. 1989. The anatomy and physiology of teleosts. In: Roberts RJ (ed). Fish pathology, pp. 13-52. Baillere and Tindall, Sydney.

Ellsaesser CF \& NW Miller. 1985. Monocytes as accessory cells in fish immune responses. Development \& Comparative Immunology 9: 803-809.

Fajer-Ávila EJ, A Roque, G Aguilar \& N Duncan. 2004. Patterns of occurrence of the platyhelminth parasites of the wild bullseye puffer (Sphoeroides annulatus) in Sinaloa, Mexico. Journal of Parasitology 90: 415-418.

Fajer-Ávila EJ, I Martínez-Rodríguez, MI Abdo de la Parra, L Alvarez-Lajonchere \& M Betancourt-Lozano. 2008. Effectiveness of freshwater treatment against Lepeophtheirus simplex (Copepoda: Caligidae) and Neobenedenia sp. (Monogenea: Capsalidae), skin parasites of bullseye puffer fish, Sphoeroides annulatus reared in tanks. Aquaculture 284: 277-280.

Ferguson HW. 2006. Systemic pathology of fish. A text and atlas of normal tissues in teleosts and their responses in disease, 366 pp. Scotian Press, London.

Geets A, H Coene \& F Ollevier. 1997. Ectoparasites of the whitespotted rabbitfish, Siganus sutor (Valenciennes, 1835) off the Kenyan Coast: distribution within the host population and site selection on the gills. Parasitology 115: 69-79.

Guillaume C, L Douellou, B Romestand \& J Trilles. 1985. Influence of a haematophageous parasite: Lernaeocera branchialis (L., 1767) (Crustacea, Copepoda, Pennellidae), on some erythrocytic constants of the host fish: Merluccius merluccius. Revue des Travaux de I'Institut des Peches Maritimes 47: 55-61.

Ho JS, CL Lin \& SN Chen. 2000. Species of Caligus Müller, 1785 (Copepoda: Caligidae) parasitic on marine fishes of Taiwan. Systematic Parasitology 46: 159-179.

Hrubec TC, JL Cardinale \& SA Smith. 2000. Hematology and plasma chemistry reference intervals for cultured tilapia (Oreochromis hybrid). Veterinary Clinical Pathology 29: 7-12.

Hughes GM. 1970. Morphological measurements on the gills of fishes in relation to their respiratory function. Folia Morphologica 18: 78-95.

Jenyns L. 1842. Fish. In: Darwin C (ed). The zoology of the voyage of H. M. S. Beagle, under the command of Captain Fitzroy, R. N. during the years 1832 to 1836 . Part IV: $97-$ 72. Smith, Elder and Co., London.

Khan RA, EM Lee \& D Barker. 1990. Lernaeocera branchialis: a potential pathogen to cod ranching. Journal of Parasitology 76: 913-917.

Larsson A, M Johansson-Sjöbeck \& R Fänge. 1976. Comparative study of some hematological and biochemical blood parameters in fishes from the Skagerrak. Journal of Fish Biology 9: 425-440.
Lester RJG \& FR Roubal. 1995. Phylum Arthropoda. In: Woo PTK (ed). Fish diseases and disorders, Vol.1. Protozoan and metazoan infections, pp. 475-598. CAB International, London.

Lin CL, JS Ho \& SN Chen. 1994. Two species of Caligus (Copepoda: Caligidae) parasitic on black sea bream (Acanthopagrus schlegeli) cultured in Taiwan. Fish Pathology 29: 253-264.

Lo CM \& S Morand. 2001. Gill parasites of Cephalopholis argus (Teleostei: Serranidae) from Moorea (French Polynesia): site selection and coexistence. Folia Parasitologica 48: 30-36.

Martins ML, M Tavares-Diaz, RY Fujimoto, EM Onaka \& DT Nomura. 2004. Haematological alterations of Leporinus macrocephalus (Osteichtyes: Anostomidae) naturally infected by Goezia leporini (Nematoda: Anisakidae) in fish pond. Arquivo Brasileiro de Medicina Veterinária e Zootecnia 56(5): 640-646.

Morales-Serna N. 2010. Ocurrencia de copépodos parásitos en el botete diana Sphoeroides annulatus (Jenyns, 1842) en el sistema lagunar Santa María La Reforma, Sinaloa, México. Tesis Doctoral, Posgrado en Ciencias del Mar y Limnología, Unidad Académica Mazatlán, UNAM, Mazatlán, 127 pp.

Palíková M, J Mares \& J Jirásek. 1999. Characteristics of leukocytes and thrombocytes of selected sturgeon species from intensive breeding. Acta Veterinary Brunensis 68: 259-264.

Paperna I \& DE Zwerner. 1982. Host- parasite relationship of Ergasilus labracis, Kroyer (Cyclopidae, Ergasilidae) and the striped bass Morone saxatilis (Walbaum) from the lower Chesapeake Bay. Annales de Parasitologie Humaine et Comparée 57: 393-405.

Pavlidis M, WC Futter, P Katharios \& P Divanach. 2007. Blood cell profile of six mediterranean mariculture fish species. Journal of Applied Ichthyology 23: 70-73.

Perna SA \& MN Fernández. 1996. Gill morphometry of facultative air-breathing loricariid fish, Hypostomus plecostomus (Walbaurm) with special emphasis on aquatic respiration. Fish Physiology and Biochemistry 15: 213-220.

Ricker WE. 1975. Computation and interpretation of biologic statistics of fish populations, pp. 209-210. Department of the Environment, Fisheries and Marine Service, Ottawa.

Rohde K, C Hayward \& M Heap. 1995. Aspects of the ecology of metazoan ectoparasites of fishes. International Journal for Parasitology 28: 263-273.

Roubal FR. 1989a. Comparative pathology of some monogenean and copepod ectoparasites on the gills of Acanthopagrus australis (family Sparidae). Journal of Fish Biology 34: 503-514.

Roubal FR. 1989b. Pathological changes in the gill filaments of Acanthopagrus australis (family Sparidae) associated with post-settlement growth of a lernaepodid copepod Alella macrotrachelus. Journal of Fish Biology 34: 333-342. 
Roubal FR. 1999. Extent of gill pathology in the toadfish Tetractenos hamiltoni caused by Naobranchia variabilis (Copepoda: Naobranchiidae). Diseases of Aquatic Organisms 35: 203-211.

Rough KM, BF Nowak \& RE Reuter. 2005. Haematology and leucocyte morphology of wild caught Thunnus maccoyii. Journal of Fish Biology 66: 1649-1659.

Santhakumar M, M Balaji \& K Ramudu. 1999. Effect of sublethal concentration of monocrotophos on erythropoeitic activity and certain haematological parameters of fish Anabus testudineus (Bloch). Bulletin of Environmental Contamination and Toxicology 63: 379-384.

Schreck CB \& PB Moyle. 1990. Methods for fish biology, 684 pp. American Fisheries Society, Bethesda.

Shigdar S, D Cook, P Jones, A Harford \& AC Ward. 2007. Blood cells of murray cod Maccullochella peelii peelii (Mitchell). Journal of Fish Biology 70: 973-980.

Silva-Souza AT, SC Almeida \& PM Machado. 2000. Effect of the infestation by Lernaea cyprinacea Linnaeus, 1758 (Copepoda, Lernaeidae) on the leucocytes of Schizodon intermedius Garavello and Britski, 1990 (Osteichthyes, Anostomidae). Brazilian Journal of Biology 60: 217-220.

Sitjà-Bobadilla A \& P Alvarez-Pellitero. 2009. Experimental transmission of Sparicotyle chrysophrii (Monogenea: Polyopisthocotylea) to gilthead seabream (Sparus aurata) and histopathology of the infection. Folia Parasitologica 56: 143-151.
Smith JL, R Wootten \& C Sommerville. 2007. The pathology of the early stages of the crustacean parasite, Lernaeocera branchialis (L.), on Atlantic cod, Gadus morhua. Journal of Fish Diseases 30: 1-11.

Tang D, M Andrews \& JM Cobcroft. 2007. The first chondracanthids (Copepoda: Cyclopoida) reported from cultured finfish, with a revised key to the species of Chondracanthus. Journal of Parasitology 93: 788-795.

Thomson DA, LT Findley \& AN Kerstitch. 2000. Reef fishes of the Sea of Cortez: The rocky-shore fishes of the Gulf of California, 353 pp. University of Texas Press, Austin.

Tierney KB, AP Farrel \& CJ Kennedy. 2004. The differential leucocyte landscape of four teleosts: juvenile Oncorhynchus kisutch, Clupea pallasi, Culaea inconstans and Pimephales promelas. Journal of Fish Biology 65: 906-919.

Timi JT. 2003. Habitat selection by Lernanthropus cynoscicola (Copepoda: Lernanthropidae): host as physical environmental, a major determinant of Niche restriction. Parasitology 127: 155-163.

Weatherley AH \& HS Gill. 1987. The biology of fish growth, pp. 14-21 Academic Press, London.

Wu Z, J Pan \& Q Qin. 1997. The lice disease in cultured banded grouper Epinephelus awoara pathology. Acta Hydrobiologica Sinica 21:207-212.

Received 24 February 2011 and accepted 18 August 2011 